\title{
III
}

\section{CASE REPORT \\ SEVERE GUMMATOUS ULCERATION OF FACE AND AURICULAR REGION}

By E. T. BURKE

In these days of modern diagnosis and free treatment, gummatous ulceration of a severe type is relatively rarely encountered in persons under the age of forty-five years. It is seen, as a rule, in elderly people whose primary infection dates back for many years.

The patient concerned here is a married woman, thirty-four years of age and under 8 stone in weight. She first attended at Salford Municipal Clinic on November I8th, I935. The history she gave was as follows :-

In September, I933, her husband suffered from a penile sore about which he refused to consult his doctor, but which he himself treated by means of some antiseptic ointment. Within a few weeks the lesion healed; but it was succeeded by a non-itchy generalised cutaneous eruption accompanied by sore throat. This, again, received no medical attention, and, in consequence, the diagnosis of syphilis was not then made.

At the end of December, I933, the patient herself suffered from sore throat and a rash. These eventually disappeared under domestic treatment. In April, I934, a dusky eruption appeared on the left side of the face between the outer canthus of the eye and the ear. She consulted a practitioner, who had a blood-test done, the result of which was " strongly positive." She was made acquainted with the diagnosis, and the necessity for treatment was emphasised. Unfortunately attendance at a clinic was deprecated; and, more unfortunate still, private treatment was not begun owing to the patient's inability to find the not inconsiderable sum requested in advance.

Between April, I934, and October, I935, the skin in the area referred to gradually became thickened. On October 
I8th, I935, a small sore appeared on the left cheek about $I$ inch from the outer canthus of the eye, and another one just behind the left ear. These sores increased in size with great rapidity. The whole of the pinna was destroyed ; there was much pain and discharge, and the patient-still being without the financial requirements for private treatment-became so depressed as to contemplate suicide. She eventually consulted another practitioner, who insisted upon her attending at the Municipal Clinic.

When first seen on November I8th, I935, the condition was that shown in photograph No. I. The most anterior lesion was a circular punched-out ulcer, nearly I inch in diameter, about $\frac{1}{4}$ inch from the outer canthus of the eye. The edges were markedly indurated and were raised so that the depth of the lesion was more than $\frac{1}{4}$ inch. The skin between this lesion and the tragus was infiltrated and of a dusky red colour, and a small area at the lower margin of this had just begun to ulcerate. The pinna had completely disappeared, only the tragus remaining. The large area shown in the photograph (No. I) around the external auditory meatus presented the typical punched-out appearance. The edges were indurated, raised and of a bluish colour. There was deep excavation and the whole of the area was bathed in foul pus. Some of the upper fibres of the sterno-mastoid muscle were visible and also some of the branches of the great auricular and small occipital nerves. Just behind the meatus the ulceration had gone very deep indeed. There was considerable danger of the anterior lesion spreading forwards and opening up the palpebral fissure, and of the posterior ulceration causing erosion of some of the vessels and of leading to middle-ear or perhaps even to meningeal damage.

Treatment, as shown in the schema on page I3, was instituted, the patient attending daily as an outpatient.

The lesions were completely healed by the forty-second day of treatment when photograph No. 7 was taken. The remaining scar is thin and tissue-papery, soft and freely movable. The present reddish tint will probably fade. The patient is able to dress her hair over the scar so that nothing of it shows.

The arsenical used was stabilarsan (arsphenamine div.D. 


\section{BRITISH JOURNAL OF VENEREAL DISEASES}

glucoside), which has been the routine preparation in the clinics over which I have had charge during the past fifteen years. This was given thrice weekly, the total dose in each seven-day period being I gm. This, in my experience, is unquestionably the best method of giving any arsphenamine preparation.

Potassium iodide has been given up in the Salford Municipal Clinic for nearly two years. Much better results have been obtained by the intravenous administration of Collosol Iodine New Solution- " C.I.N.S.," 0.8 per cent. This is given in split doses, so that a total amount of from Io to 20 c.c. is received per week.

For the first three weeks of treatment the lesions were dressed daily with lint soaked in pure Iodargol. This preparation not only has a remarkable power of rapidly cleaning these purulent lesions, but it has at the same time apparently a fibrolytic effect. The resultant scar is very flexible and causes little deformity.

The following points are, I think, of interest :-

(I) The sex and age of the patient.

(2) The gummatous condition began about two years after the primary infection, which was October-November, I933.

(3) The patient had received no previous treatment.

(4) The extremely rapid destruction of tissue between October I 8 th and November I8th, I935.

(5) The rapid and satisfactory healing under the regimen indicated in the schema on p. I3.

(6) The high total dosage of arsphenamine which may be safely administered by the thrice-weekly method of injection.

The photographs, which are life size, were taken with a Kodak $\frac{1}{2}$ plate Clinical Camera on Eastman Portrait Panchromatic films. The lighting used was two 500-watt floodlamps each at 3 feet distance from the patient. The stop used was $f / I 6$ and the exposure was half a second. 
SEVERE GUMMATOUS ULCERATION OF FACE

\begin{tabular}{|c|c|c|c|c|c|c|}
\hline Week. & Day. & Date. & Stab. & C.I.N.S. & Dressing. & \\
\hline I. & $\begin{array}{l}\text { I } \\
2 \\
3 \\
4 \\
5 \\
6 \\
7\end{array}$ & $\begin{array}{l}I 8 / \mathrm{II} / 35 \\
\mathrm{I} 9 / \mathrm{II} / 35 \\
20 / \mathrm{II} / 35 \\
2 \mathrm{I} / \mathrm{II} / 35 \\
22 / \mathrm{II} / 35 \\
23 / \mathrm{II} / 35 \\
24 / \mathrm{II} / 35\end{array}$ & $\begin{array}{l}0 \cdot 45 \\
\frac{0 \cdot 30}{-} \\
0 \cdot 25 \\
-\end{array}$ &  & $\begin{array}{c}\text { Iodargol } \\
\text {," } \\
\text { ", } \\
\text {," } \\
\text { ", } \\
\text {," }\end{array}$ & Photo No. I \\
\hline II. & $\begin{array}{r}8 \\
9 \\
\text { IO } \\
\text { II } \\
\text { I2 } \\
\text { I3 } \\
\text { I4 }\end{array}$ & $\begin{array}{c}25 / \mathrm{II} / 35 \\
26 / \mathrm{II} / 35 \\
27 / \mathrm{II} / 35 \\
28 / \mathrm{II} / 35 \\
29 / \mathrm{II} / 35 \\
30 / \mathrm{II} / 35 \\
\mathrm{I} / \mathrm{I} 2 / 35\end{array}$ & $\begin{array}{l}0 \cdot 45 \\
\frac{0}{0 \cdot 30} \\
\frac{0 \cdot 25}{25} \\
-\end{array}$ & $\begin{array}{l}4 \text { c.c. } \\
3 \text { c.c. } \\
\text { - c.c. } \\
-\end{array}$ & $\begin{array}{l}\text {, } \\
, " \\
, \\
, " \\
,, \\
\text {," }\end{array}$ & Photo No. 2 \\
\hline III. & $\begin{array}{l}\text { I5 } \\
\text { I6 } \\
\text { I7 } \\
\text { I8 } \\
\text { I9 } \\
20 \\
21\end{array}$ & $\begin{array}{l}2 / \mathrm{I} 2 / 35 \\
3 / \mathrm{I} 2 / 35 \\
4 / \mathrm{I} 2 / 35 \\
5 / \mathrm{I} 2 / 35 \\
6 / \mathrm{I} 2 / 35 \\
7 / \mathrm{I} 2 / 35 \\
8 / \mathrm{I} 2 / 35\end{array}$ & $\begin{array}{l}0.45 \\
\frac{0 \cdot 30}{-} \\
0 \cdot 25 \\
-\end{array}$ & 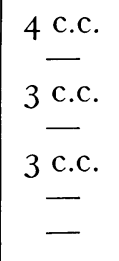 & $\begin{array}{l}\text {," } \\
, " \\
,, \\
, \\
\text {," } \\
\text {," }\end{array}$ & Photo No. 3 \\
\hline IV. & $\begin{array}{l}22 \\
23 \\
24 \\
25 \\
26 \\
27 \\
28\end{array}$ & $\begin{array}{r}9 / \mathrm{I} 2 / 35 \\
\mathrm{IO} / \mathrm{I} 2 / 35 \\
\mathrm{II} / \mathrm{I} 2 / 35 \\
\mathrm{I} 2 / \mathrm{I} 2 / 35 \\
\mathrm{I} 3 / \mathrm{I} 2 / 35 \\
\mathrm{I} 4 / \mathrm{I} 2 / 35 \\
\mathrm{I} 5 / \mathrm{I} 2 / 35\end{array}$ & $\begin{array}{l}\frac{0 \cdot 45}{-} \\
\frac{0 \cdot 30}{-} \\
\frac{0 \cdot 25}{-}\end{array}$ & $\begin{array}{l}4 \text { c.c. } \\
3 \text { c.c. } \\
\overline{3 \text { c.c. }} \\
- \\
-\end{array}$ & $\begin{array}{c}\text { Ung. Viozin } \\
\text {," } \\
\text {," } \\
\text {," } \\
\text {," } \\
\text {,, }\end{array}$ & Photo No. 4 \\
\hline V. & $\begin{array}{l}29 \\
30 \\
31 \\
32 \\
33 \\
34 \\
35\end{array}$ & $\begin{array}{l}\mathrm{I} 6 / \mathrm{I} 2 / 35 \\
\mathrm{I} 7 / \mathrm{I} 2 / 35 \\
\mathrm{I} 8 / \mathrm{I} 2 / 35 \\
\mathrm{I} 9 / \mathrm{I} 2 / 35 \\
20 / \mathrm{I} 2 / 35 \\
2 \mathrm{I} / \mathrm{I} 2 / 35 \\
22 / \mathrm{I} 2 / 35\end{array}$ & $\begin{array}{l}0 \cdot 45 \\
\frac{-}{0 \cdot 30} \\
\frac{0 \cdot 25}{-} \\
-\end{array}$ & $\begin{array}{l}4 \text { c.c. } \\
\overline{3 \text { c.c. }} \\
\overline{3 \text { c.c. }} \\
-\end{array}$ & $\begin{array}{l}\text {," } \\
\text {," } \\
\text { ", } \\
\text {, } \\
\text {," }\end{array}$ & Photo No. 5 \\
\hline \multirow[t]{2}{*}{ VI. } & $\begin{array}{l}36 \\
37 \\
38 \\
39 \\
40 \\
4 I \\
42\end{array}$ & $\begin{array}{l}23 / \mathrm{I} 2 / 35 \\
24 / \mathrm{I} 2 / 35 \\
25 / \mathrm{I} 2 / 35 \\
26 / \mathrm{I} 2 / 35 \\
27 / \mathrm{I} 2 / 35 \\
28 / \mathrm{I} 2 / 35 \\
29 / \mathrm{I} 2 / 35\end{array}$ & $\begin{array}{l}0.45 \\
\frac{0 \cdot 30}{0} \\
\frac{0 \cdot 25}{-} \\
-\end{array}$ & $\begin{array}{l}4 \text { c.c. } \\
3 \text { c.c. } \\
\text { - } \\
\text { c.c. } \\
-\end{array}$ & \multirow[t]{2}{*}{$\begin{array}{l}\text {, } \\
\text { ", } \\
\text {, } \\
\text { ", } \\
\text {," }\end{array}$} & \multirow[t]{2}{*}{ Photo No. 7} \\
\hline & & Total ... & $6 \cdot 00$ & 59 c.c. & & \\
\hline
\end{tabular}


SEVERE GUMMATOUS ULCERATION OF FACE

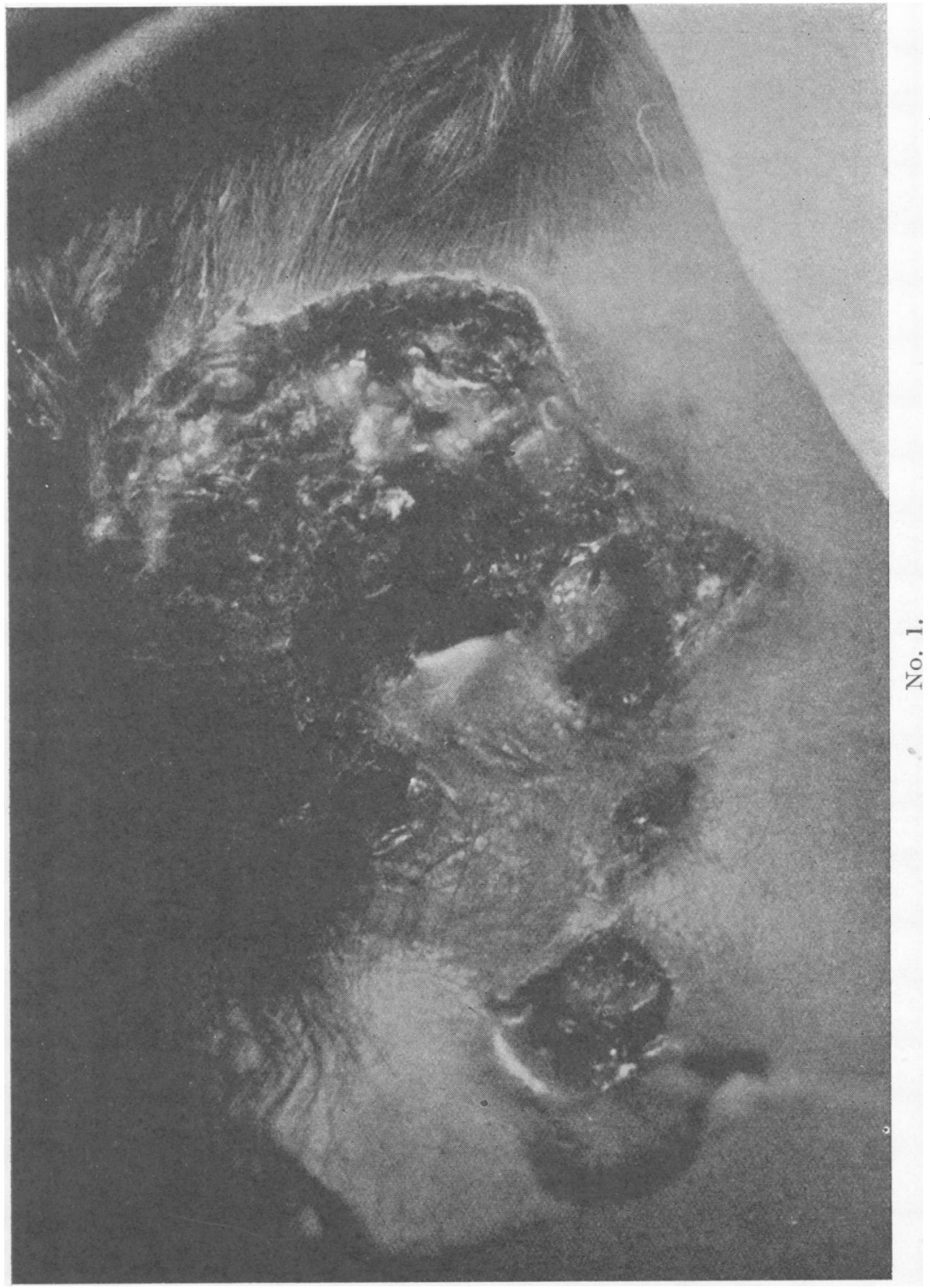




\section{SEVERE GUMMATOUS ULCERATION OF FACE}

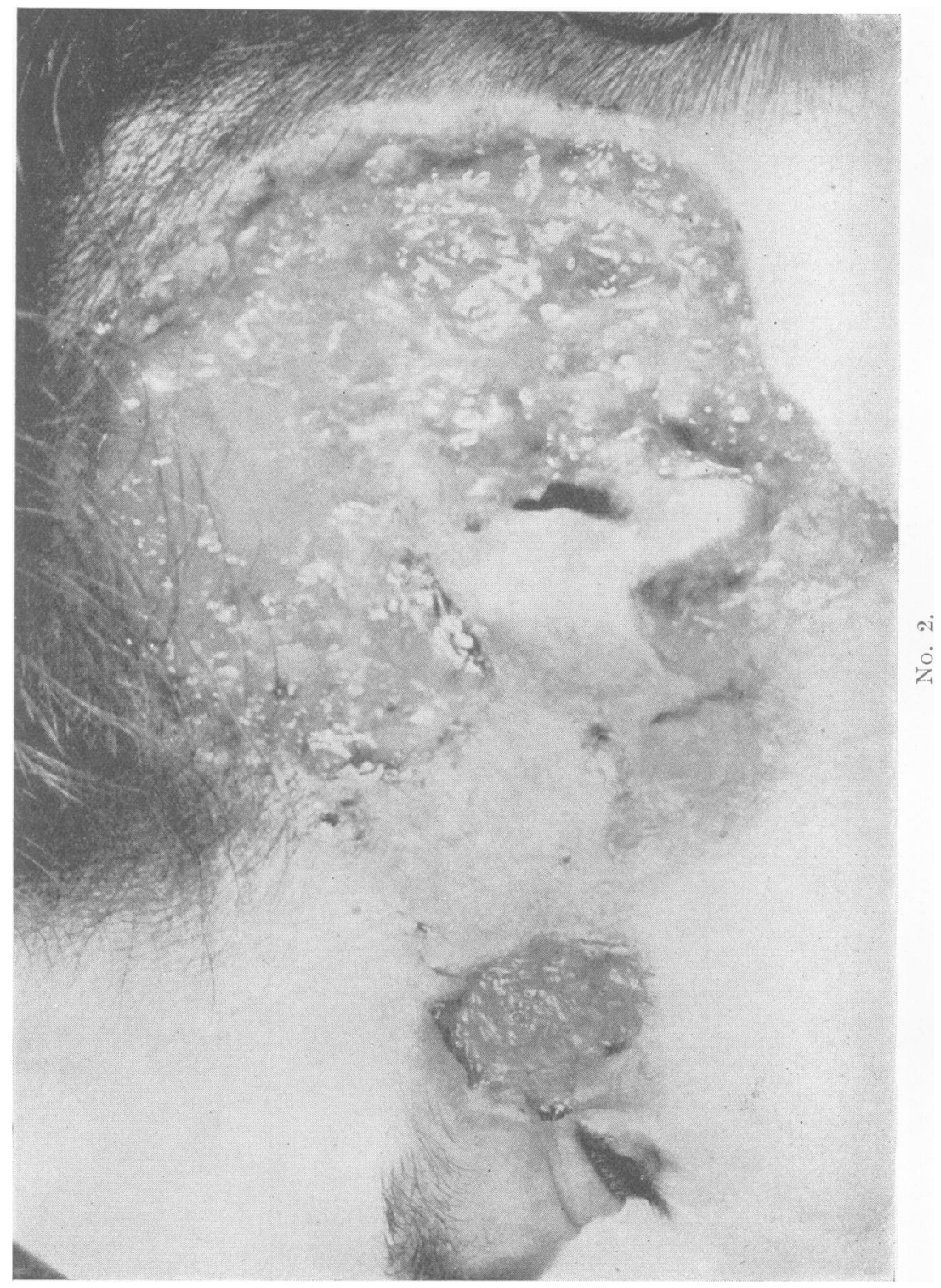


SEVERE GUMMATOUS ULCERATION OF FACE
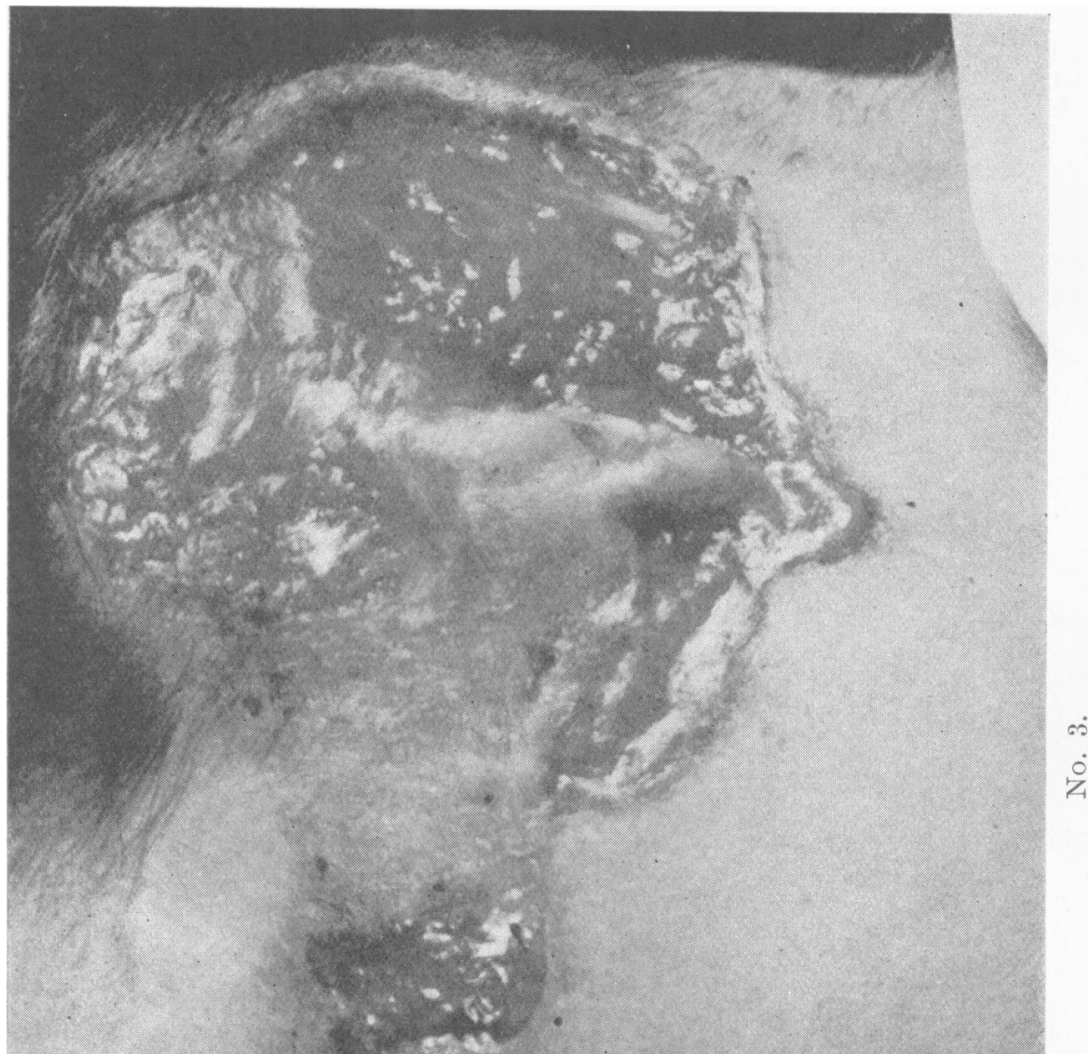

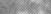


SEVERE GUMMATOUS ULCERATION OF FACE

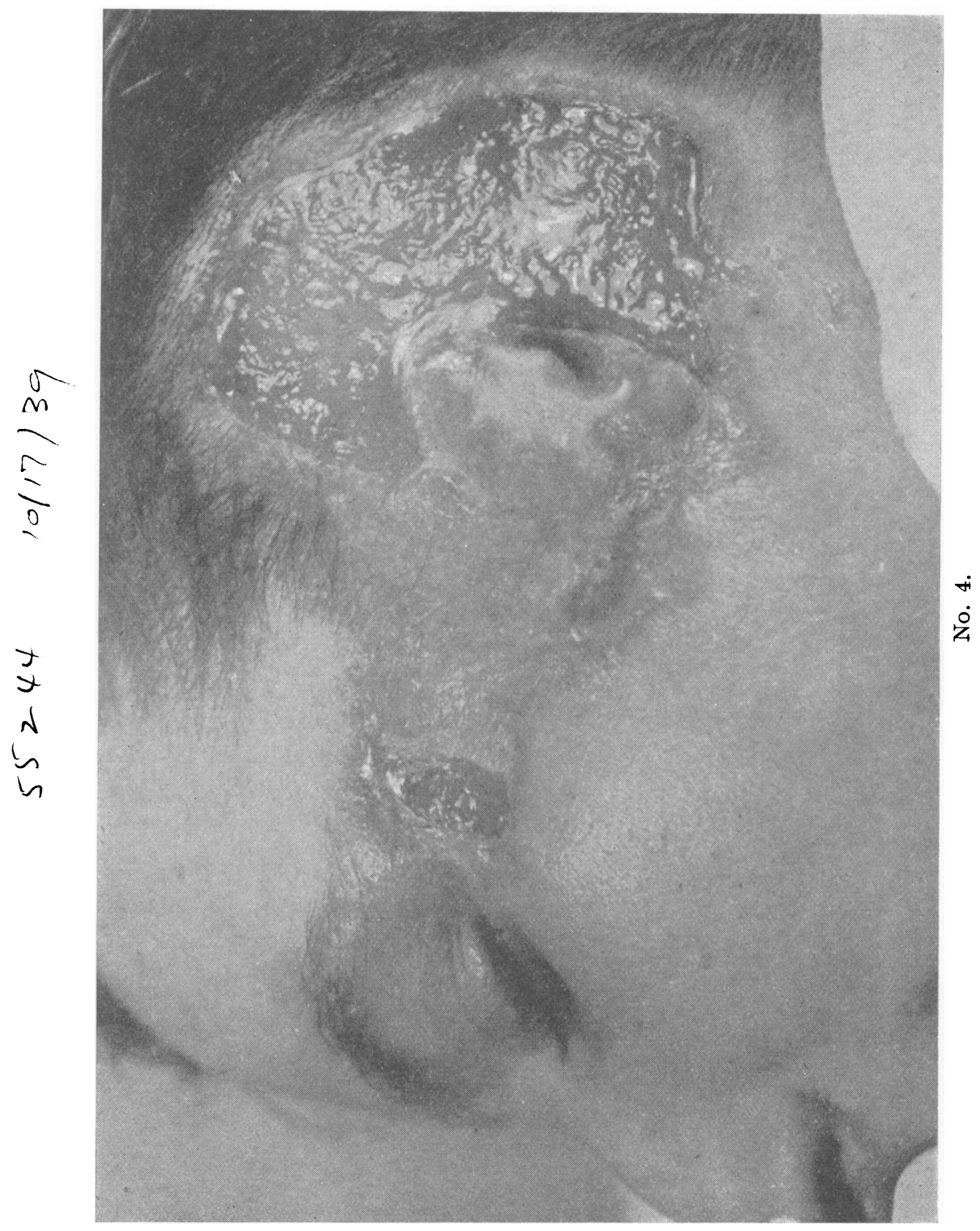


SEVERE GUMMATOUS ULCERATION OF FACE

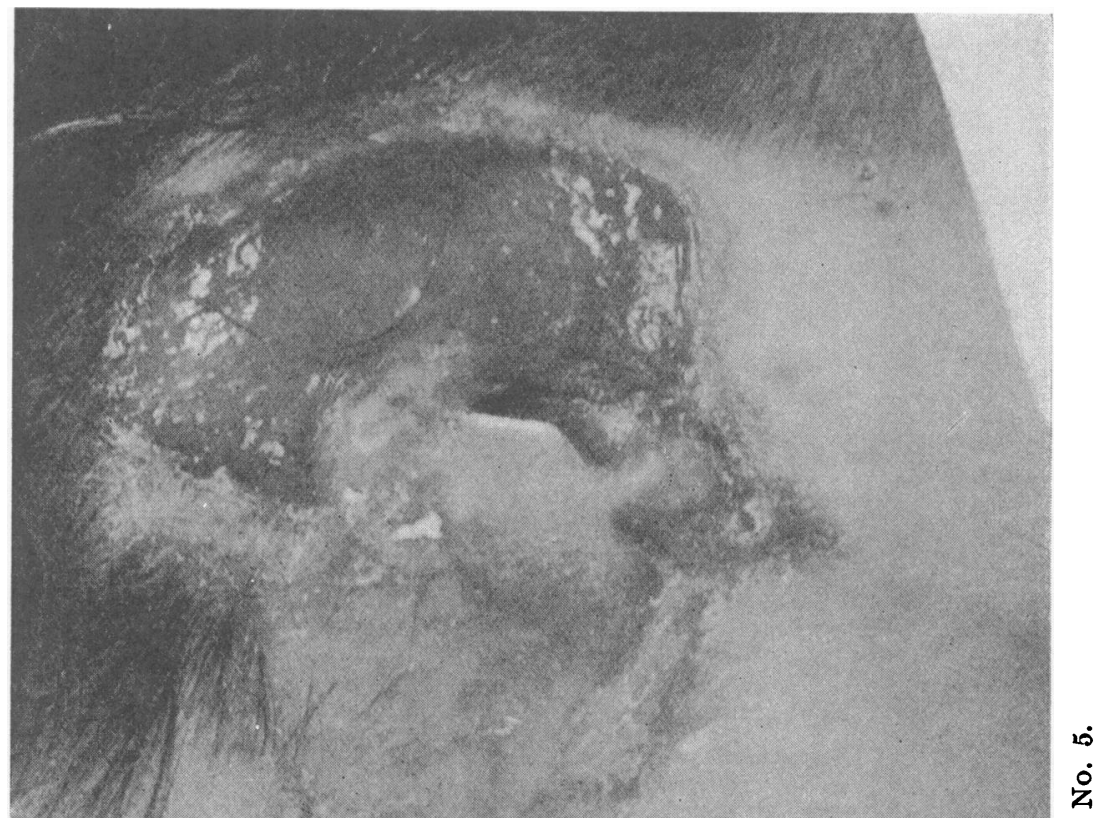


SEVERE GUMMATOUS ULCERATION OF FACE




SEVERE GUMMATOUS ULCERATION OF FACE

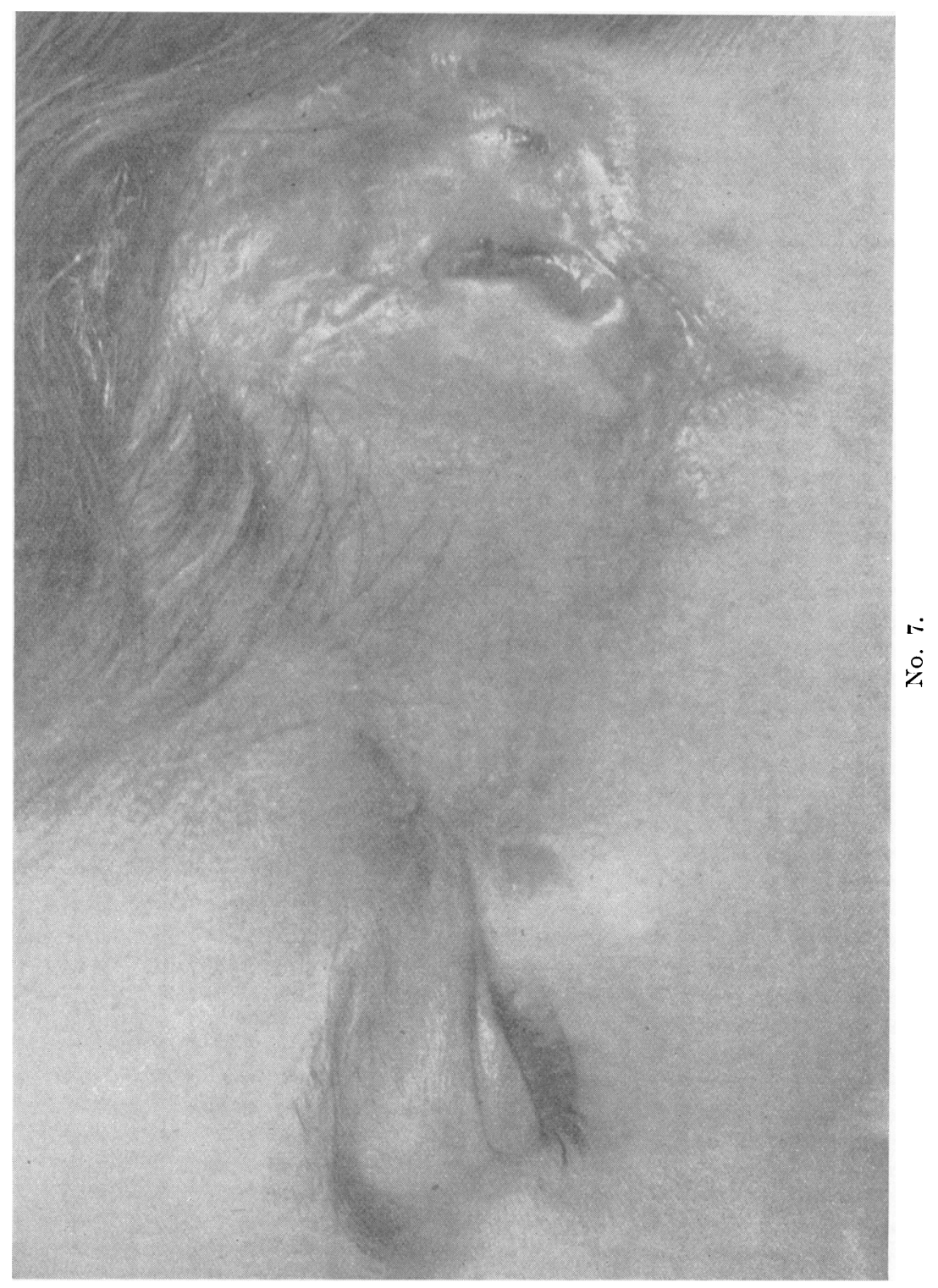

